\title{
INVOLVEMENT OF CENTRAL $\beta$-ADRENERGIC CIRCUITRY IN FOOD AND WATER INTAKE IN CHICKENS
}

\author{
Received December 13, 2013
}

\begin{abstract}
We examined the effects of intracerebroventricular (i.c.v.) microinjections of $\alpha, \beta_{1,2}$-adrenergic agonist, isoproterenol (ISOP), and of a $\beta_{1,2}$-adrenoceptor blocker, propranolol (PROP), on food and water intake in broiler cockerels deprived of food and water for $3 \mathrm{~h}$. We found that ISOP, at a $200 \mathrm{nM}$ concentration and not smaller, significantly $(P \leq 0.05)$ increased food intake but not water intake. PROP microinjected in different doses (20-80 mM) significantly $(P \leq 0.05)$ decreased food intake. These observation suggest a direct orexigenic role for the $\beta$ - and $\beta$-adrenergic systems in the regulation of food intake in chickens. The significant $(P \leq 0.05)^{2}$ effect of i.c.v. injections of PROP (transient increase in water intake) implies a role of the adrenergic system, possibly via $\alpha$-adrenoceptors, in the regulation of water intake in broilers, which is food intake-independent.
\end{abstract}

Keywords: food and water intake, broiler chickens, intracerebroventricular injections, isoproterenol, propranolol.

\section{INTRODUCTION}

As was shown, hypothalamic or intracerebroventricular (i.c.v.) microinjections of norepinephrine (NE) stimulates feeding in both satiated and hungry rats [1$3]$. At the same time, such injections inhibited drinking in thirsty rats [3] but stimulated water intake in satiated rats [4]. It was proposed that NE-induced increase in food intake is associated with stimulation of $\beta_{2}$-adrenoceptors $[2,3,5,6]$. At the same, it was reported that hypothalamic injections of agonists of $\beta_{1}-$ and $\beta_{2}$-adrenoreceptors reduced feeding in rats [7].

Intracerebroventricular, i.c.v., injections of NE did not stimulate feeding behavior of both broiler- and layer-type chickens [8,9], while such administration of epinephrine stimulated food intake [8,9]. Most research on food intake in avian species has been focused on $\alpha$-adrenoceptors, while information on $\beta$-adrenoceptors is scarce. It has been shown that $\beta_{1}-$ adrenergic agonists stimulated food intake in chickens [10], and $\beta$-receptor agonists stimulated that in broilers [11] and layers [12]. A $\beta_{3}$-agonist reduced food intake of chicks under ad libitum, but not fasting, feeding conditions [13]. In rats, hypophagia was induced by administration of $\beta_{3}$-agonists [14-16], but a

${ }^{1}$ Department of Basic Sciences, Faculty of Veterinary Medicine, University of Tehran, Iran.

Correspondence should be addressed to A. Baghbanzadeh

(e-mail: ali.baghbanzadeh@yahoo.com). $\beta$-antagonist exerted no effect on food intake [14]. Injections of an adrenergic $\beta_{1}$ - and $\beta_{2}$-adrenoreceptor agonist into the lateral hypothalamic area decreased food and, especially, water intake in broilers deprived of food and water for $3 \mathrm{~h} \mathrm{[17].}$

In our study, we examined the effect of i.c.v. injections of isoproterenol (ISOP), a $\beta_{1}-$ and, especially, $\beta_{2}$-adrenoceptor agonist, and of propranolol (PROP), a nonselective $\beta$-blocker, on food and water intake in broilers.

\section{METHODS}

Forty-eight (for each experiment) 1-day-old Ross 308 broiler cockerels (Eshragh Hatcheries, Varamin, Iran) were housed until 2-week age in a battery-heated room with continuous lighting; then they were transferred to individual fully computerized cages (TSE Systems, Germany), by which the amount of food and water intake within each 10-min-long interval was automatically recorded. Chickens were provided with free access to water and to a broiler starter mash ratio (Chineh Feed Mill, Iran) containing 21\% protein and $3200 \mathrm{kcal} / \mathrm{kg}$ metabolizable energy in individual feeders. The room temperature was maintained at $22 \pm 2{ }^{\circ} \mathrm{C}$.

Surgery. When chickens weighed approximately $750 \pm 50 \mathrm{~g}$, they were anesthetized and underwent 
surgery according to the procedure mentioned before [18] considering coordinates of the cerebral ventricles [19].

Chemicals. ISOP (a $\beta$ - and $\beta$-adrenoceptor agonist) and PROP (nonselective $\beta$-blocker) were purchased from Sigma-Aldrich Chemie, Germany. All solutions were prepared in a pyrogen-free $0.9 \% \mathrm{NaCl}$ solution (saline); the latter also served as the control in microinjections.

I.c.v. Injections. Five experiments were conducted to determine the effects of i.c.v. microinjections of ISOP and PROP on food and water intake; fortyeight chickens were used in each experiment. In a separate experiment, all solutions were injected on the same day in replicates of 12 birds, and feeding behavior was monitored. Injections were made with a 29-gauge thin-walled stainless-steel injection cannula that extended $0.5 \mathrm{~mm}$ beyond the guide cannula. The injection cannula was connected to a 10- $\mu 1$ Hamilton syringe via a $50-\mathrm{cm}$-long polyethylene tubing. Several days before starting the experiments, the chickens were restrained daily to acclimate to the procedure. They were deprived of food and water for $3 \mathrm{~h}$ prior to injection. Solutions were injected within a 30 -seclong interval, and the injection cannula remained in place for an additional $30 \mathrm{sec}$ before removal. After injection, all chickens were returned to their cages. Tubing and syringes were kept in $70 \%$ ethanol, and the glassware was autoclaved to render materials pyrogenfree. Proper location of the guide cannula was verified according to i.c.v. injections of methylene blue at the end of the experiments after slicing of the frozen brain tissue.

Just after the injections, fresh food (in experiments 1,3 , and 5) and fresh water (in experiments 2 and 4) were provided for the birds.

Experiments 1 and 2: Effects of I.c.v. Injections of ISOP on Food and Water Intake. Broilers in experiments 1 and 2 were injected with pure saline (control), or 50, 100, and $200 \mathrm{nM}$ ISOP in $2.5 \mu 1$ of saline into the right lateral ventricle. Cumulative food and water intake $(\mathrm{g})$ was recorded at $15,30,60,120$, and 180 min post injection (p.i).

Experiments 3 and 4: Effects of I.c.v. Injections of PROP on Food and Water Intake. Experiments 3 and 4 were done to examine the effects of i.c.v. injections of 20,40 , or $80 \mu \mathrm{M}$ PROP in $2.5 \mu 1$ saline and carried out in the same mode as those described above. The doses of ISOP and PROP were based on the result of a previous study on rats [20].

Experiment 5: Effect of I.c.v. Injections of
ISOP on Food Intake in PROP-Pretreated Birds. In experiment 5 , cumulative food intake $(\mathrm{g})$ of broiler cockerels following i.c.v. injections of saline and combinations of effective doses of the agonist $(400 \mathrm{nM})$ and antagonist $(40,80$, or $160 \mu \mathrm{M})$, each in a $1.25 \mu$ l volume, was recorded at $15,30,60,120$, and 180 min post-injection.

In control groups, saline was used in the same volume and times of i.c.v. injections were similar to those in the treated groups.

Statistical Analysis. Cumulative food and water intake (g) was subjected to one-way analysis of variance (ANOVA) at each time period. For treatments showing the main effect by ANOVA, means were compared by the post-hoc Bonferroni's and Duncan's multiple range tests. $P \leq 0.05$ was considered confirmation of significant differences between groups. All data are presented below as means \pm s.d.

\section{RESULTS}

The effects of i.c.v. injections of ISOP on food intake are summarized in Fig. 1. Injections of this agent at a concentration of $200 \mathrm{nM}$ significantly $(P \leq 0.05)$ increased food intake during the experiment.

The effects of i.c.v. injections of ISOP on water intake are summarized in Fig. 2. As can be seen, none of the doses used evoked a significant change in water

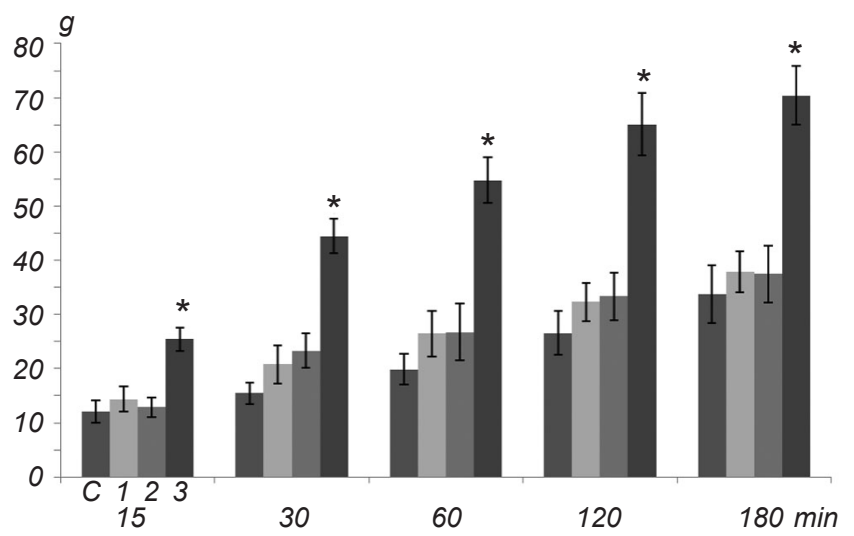

F i g. 1. Cumulative food intake (g) in broiler cockerels following i.c.v. microinjections of three different doses of isoproterenol (ISOP). C is the control (injections of saline); 1-3 are experimental groups injected with 50,100, and $200 \mathrm{nM}$ ISOP solutions. Time, min, after injections is shown below the diagrams. Means \pm s.d. are shown; asterisks indicate cases of significant $(P<0.05)$ differences from the control.

P и с. 1. Кумулятивні значення споживання їжі (г) півникамибройлерами після внутрішньошлуночкових мікроін'єкцій ізопротеренолу в трьох різних дозах. 


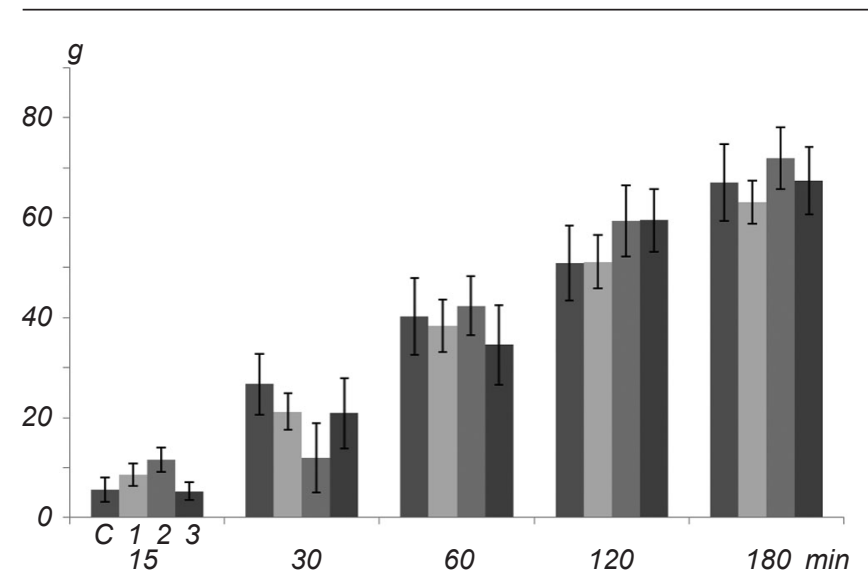

F i g. 2. Cumulative water intake $(\mathrm{g})$ in broiler cockerels following i.c.v. microinjections of three different doses of ISOP. Designations are the same as in Fig. 1.

P и с. 2. Кумулятивні значення споживання води півникамибройлерами після внутрішньошлуночкових мікроін'єкцій ізопротеренолу.

intake.

The effects of i.c.v. injections of PROP on food intake is summarized in Fig. 3. Such injections, at all doses used, decreased food intake during the experiment; the respective shift demonstrated a significant $(P \leq 0.05)$ difference at $30 \mathrm{~min}$ postinjection.

The effect of i.c.v. injection of PROP on water intake is summarized in Fig. 4. PROP transiently increased water intake at concentrations of 20 and $40 \mu \mathrm{M}$ at the 30 th and 15 th min post-injection.

The effect of i.c.v. injection of ISOP on food intake

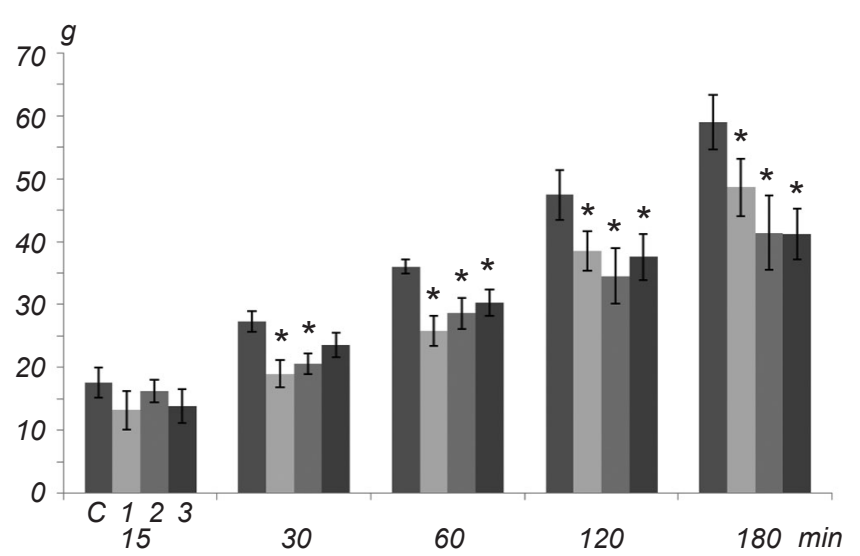

F i g. 3. Cumulative food intake ( $\mathrm{g}$ ) of broiler cockerels following i.c.v. microinjections of three different doses of propranolol (PROP). In groups 1-3, 20, 40, and $80 \mu \mathrm{M}$ solutions were injected; other designations are the same as in Figs. 1 and 2.

P и с. 3. Кумулятивні значення споживання їжі півникамибройлерами після внутрішньошлуночкових мікроін'єкцій пропранололу в трьох різних дозах.

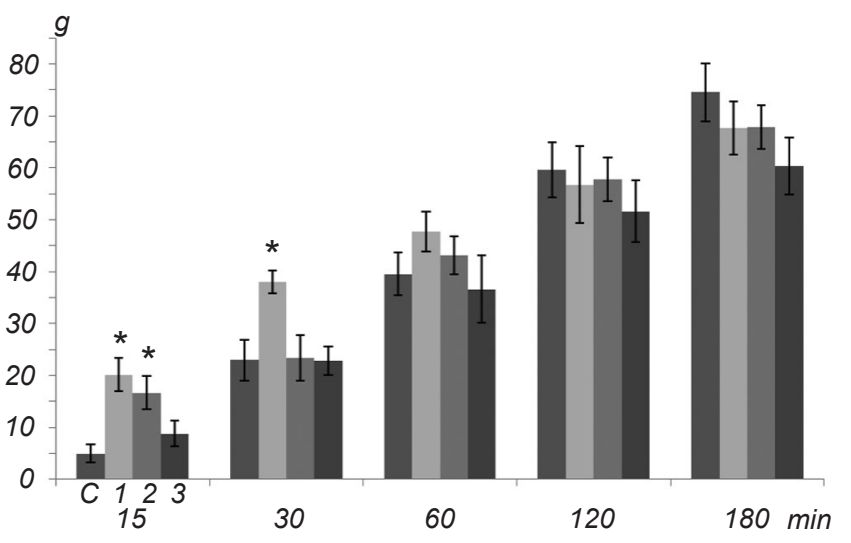

F i g. 4. Cumulative water intake ( $g$ ) in broiler cockerels following i.c.v. microinjections of three different doses of PROP. Designations are the same as in Fig. 3.

P и с. 4. Кумулятивні значення споживання води півникамибройлерами після внутрішньошлуночкових мікроін'єкцій пропранололу.

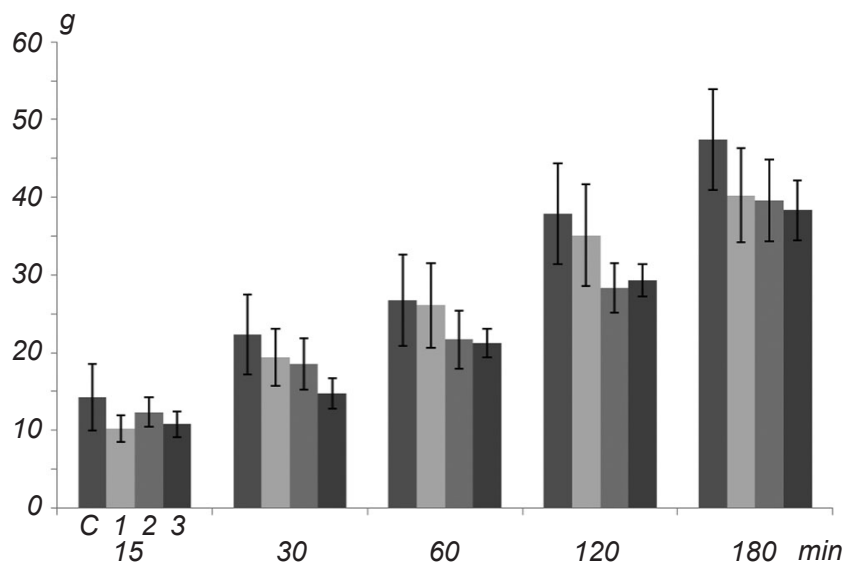

F i g. 5. Cumulative food intake ( $g$ ) in broiler cockerels following i.c.v. microinjections of $400 \mathrm{nM}$ ISOP pretreated with i.c.v. injections of three different doses of PROP (40, 80, and $160 \mu \mathrm{M})$.

P и с. 5. Кумулятивні значення споживання їжі півникамибройлерами після внутрішньошлуночкових мікроін'єкцій ізопротеренолу (400нМ), яким передували мікроін'єкції пропранололу в трьох різних дозах (40,80 або 160 мкМ).

in PROP-pretreated birds is summarized in Fig. 5. Pretreatment with PROP, a $\beta$-adrenergic antagonist, practically abolished the effect of ISOP on food intake.

\section{DISCUSSION}

There is compelling evidence that adrenergic synaptic transmission plays an important role in the control of feeding [11, 21, 22] and drinking behavior. Any alteration of the brain NE level can either increase or decrease eating depending on the site of application 
and other testing variables [6]. In our study, possible involvement of the central $\beta_{1}$ and $\beta_{2}$-adrenergic systems on food and water intake in broiler chickens was examined.

Experiment 1 showed a significant $(P \leq 0.05)$ increase in food intake, but only at the highest dose of ISOP applied. This is in agreement with observations of Baile et al. [23], who showed that i.c.v. injections of ISOP intensified feeding in sheep and cattle, although Leibowitz [7] indicated that hypothalamic injection of ISOP suppressed feeding behavior in rats. Stujii and Bray [24] showed that administration of a $\beta_{2}-$ adrenergic agonist into the third cerebral ventricle reduced food intake in Zucker fatty and lean rats. Our previous findings [17] showed that injections of low doses of ISOP into the intralateral hypothalamic area resulted in a significant transient reduction of food intake in broilers, while higher doses of this agent induced increased intake; the latter change was, however, statistically insignificant.

The results of Experiment 2 indicated that ISOP at all doses used exerted no significant $(P \leq 0.05)$ effects on water intake in broilers. Our previous data where much higher doses of ISOP were microinjected into the hypothalamus showed an inhibitory effect on water intake [17]. In rats, some investigations of the effects of peripheral administration of ISOP and consequent increased water intake through stimulation of $\beta_{1}$ - and $\beta_{2}$-adrenoceptor activity, respectively, resulted in an increase in renin release and decrease in the blood pressure [25].

In Experiment 3, a significantly decreased $(P \leq 0.05)$ food intake at all doses of PROP used was found 30 min post injection. This is consistent with our findings in Experiment 1 and suggests an orexigenic role for $\beta_{1}$ - and/or $\beta_{2}$-adrenoceptors. Thus, even the lowest dose of PROP exerted an inhibitory effect on food intake. This is not consistent with our previous findings where lower doses of PROP into the hypothalamus increased food intake significantly [17]. Tsujii et al. [26] indicated that PROP injected into the third cerebral ventricle increased food intake in lean rats, but no change was observed in fatty rats. Naka et al. [27] showed that application of timolol, a $\beta$-adrenoceptor antagonist, to the bed nucleus of the stria terminalis has no effect on food intake in rats.

The results of Experiment 4 indicated that PROP induced a significant $(P \leq 0.05)$ transient increase in water intake by chickens. These observations are in agreement with our previous findings [17] that suggested a stimulatory effect of PROP on food and water intake. As was found [28], blocking of one type of adrenoreceptors may enhance the responsiveness of the other type. We believe that occupation of $\beta$-receptors allows the endogenous epinephrine and NE to be exposed more specifically to $\alpha$-receptors. It has been indicated that stimulation of $\alpha$-receptors has a stimulatory effect on food and water intake in mammals [29] and birds [12, 30].

Our findings in Experiment 5 indicated that the effect of ISOP on food intake is agonist-specific and can be abolished by pretreatment with PROP. This is in accordance with our previous findings [17]. Naka et al. [27] showed that, unlike what is observed in chickens, activation of $\beta$-adrenoceptors in the rat bed nucleus of the stria terminalis decreases food intake, and this effect can be abolished by co-administration of a $\beta$-adrenoceptor antagonist.

It was shown that NE exerts a mild effect on $\beta_{2}$ receptors, whereas epinephrine and ISOP are very active with respect to $\beta_{2}$-receptor sites [31]. On the other hand, epinephrine, and not NE, stimulates food intake in birds. Thus, it may be concluded that the orexigenic effects of ISOP are more dependent on $\beta_{2}$ adrenoceptors.

Therefore, our findings suggest that i.c.v. injections of the $\beta$-adrenoreceptor agonist into food-and waterdeprived broiler cockerels induce an orexigenic effect but do not influence water intake. The orexigenic effect is specific and can be abolished by pretreatment with a $\beta$-adrenoceptor blocker. The latter agent induces significant transient stimulation of water intake that might result from relative activation of $\alpha$-adrenoceptors exposed to the constitutively released neurotransmitter.

Further investigations should be carried out to elucidate separate effects of $\beta_{1}$ - and $\beta_{2}$-adrenoceptors using specific agonists and antagonists of these adrenergic receptor subtypes. Also, the effect of $\beta$-receptors should be studied under conditions where $\alpha$-adrenoceptors are blocked. The effects of longer and shorter food and water deprivations will also be a potential topic for future studies.

Acknowledgments. This research was supported by a grant from the Research Council of the Faculty of Veterinary Medicine, University of Tehran.

Animal handling and experimental procedures were performed according to the Guide for Care and Use of Laboratory Animals published by US National Institutes of Health (NIH publication No. 85-23, revised 1996), and also with the current ethical codes of Iran for handling laboratory animals. 
The authors of this study, A. Baghbanzadeh, Z. Hamidiya, and M. H. Geranmayeh, confirm that the research and publication of the results were not associated with any conflicts regarding commercial or financial relations, relations with organizations and/or individuals who may have been related to the study, and interrelations between co-authors of the article.

\section{А. Багхбанзаде, 3. Хамідія ${ }^{l}$, М. Х. Геранмайєх ${ }^{l}$}

\section{РОЛЬ ЦЕНТРАЛЬНИХ СПОЖИВАННІ ЇЖІ ТА ВОДИ КУРЧАТАМИ}

${ }^{1}$ Тегеранський університет (Іран).

P е 3 ю м е

Було досліджено впливи інтрацеребровентрикулярних мікроін'єкцій агоніста $\beta_{1,2}$-адренорецепторів ізопротеренолу та блокатора $\beta_{1,2}$-адренорецепторів пропранололу на споживання їжі та води бройлерами-півниками, позбавленими їжі та питва протягом 3 год. Виявилося, що ізопротеренол у концентрації 200 нМ (але не менше) істотно $(P \leq 0.05)$ посилював споживання їжі, але не води. Пропранолол, ін'єкований у різних дозах (20-80 мкМ), вірогідно зменшував споживання їжі. Отримані дані свідчать на користь гіпотез про орексигенну роль $\beta$ - та $\beta$-адренергічних систем у регуляції споживання їжі курчатами. Істотний $(P \leq 0.05)$ ефект ін'єкцій пропранололу (тимчасове зростання споживання води) вказує на певну роль адренергічної системи щодо регуляції споживання води бройлерами; цей ефект, вірогідно, реалізується через $\alpha$-адренорецептори та $\epsilon$ незалежним від впливів на споживання їжі.

\section{REFERENCES}

1. S. P. Grossman, "Eating or drinking elicited by direct adrenergic or cholinergic stimulation of hypothalamus," Science, 132, No. 3422, 301-302 (1960).

2. C. K. Goldman, L. Marino, and S. F. Leibowitz, "Postsynaptic $\beta_{2}$-noradrenergic receptors mediate feeding induced by paraventricular nucleus injection of norepinephrine and clonidine," Eur. J. Pharmacol., 115, No. 1, 11-19 (1985).

3. S. F. Leibowitz and C. Rossakis, "Mapping study of brain dopamine- and epinephrine-sensitive sites which cause feeding suppression in the rat," Brain Res., 172, No. 1, 101-113 (1979).

4. S. P. Grossman, "Direct adrenergic and cholinergic stimulation of hypothalamic mechanisms," Am. J. Physiol., 202, 872-882 (1962).

5. C. Broekkamp and J. M. van Rossum, "Clonidine induced intrahypothalamic stimulation of eating in rats," Psychopharmacologia, 25, No. 2, 162-168 (1972).

6. P. J. Wellman, "Norepinephrine and the control of food intake," Nutrition, 16, No. 10, 837-842 (2000).

7. S. F. Leibowitz, "Reciprocal hunger-regulating circuits involving alpha- and beta-adrenergic receptors located, respectively, in the ventromedial and lateral hypothalamus,"
Proc. Natl. Acad. Sci. USA, 67, No. 2, 1063-1070 (1970).

8. D. M. Denbow, J. A. Cherry, P. B. Siegel, and H. P. Van Krey, "Eating, drinking and temperature response of chicks to brain catecholamine injections," Physiol. Behav., 27, No. 2, 265-269 (1981).

9. D. M. Denbow, H. P. Van Krey, M. P. Lacy, and T. J. Dietrick, "Feeding, drinking and body temperature of Leghorn chicks: Effects of ICV injections of biogenic amines," Physiol. Behav., 31, No. 1, 85-90 (1983).

10. D. M. Denbow, H. P. Van Krey, and P. B. Siegel, "Selection for growth alters the feeding response to injections of biogenic amines," Pharmacol. Biochem. Behav., 24, No. 1, 39-42 (1986).

11. T. Bungo, M. Shimojo, Y. Masuda, et al., "Induction of food intake by a noradrenergic system using clonidine and fusaric acid in the neonatal chick," Brain Res., 826, No. 2, 313-316 (1999).

12. T. Tachibana, K. Sugahara, H. Ueda, and M. A. Cline, "Role of adrenergic alpha-2-receptors on feeding behavior in layer-type chicks," Gen. Comp. Endocrinol., 161, No. 3, 407-411 (2009).

13. T. Tachibana, T. Takagi, E. S. Saito, et al., "Beta 3-adrenergic receptor is involved in feeding regulation in chicks," Comp. Biochem. Physiol. - Mol. Integr. Physiol., 135, No. 3, 403-409 (2003)

14. S. A. Kanzler, A. C. Januario, and M. A. Paschoalini, "Involvement of $\beta 3$-adrenergic receptors in the control of food intake in rats," Braz. J. Med. Biol. Res., 44, No. 11, 1141-1147 (2011).

15. M. Castillo-Melŭndez, M. J. McKinley, and R. J. Summers, "Intracerebroventricular administration of the b3-adrenoceptor agonist CL 316243 causes Fos immunoreactivity in discrete regions of rat hypothalamus," Neurosci. Lett., 290, No. 3, 161$164(2000)$.

16. T. Yoshida, Y. Takakura, and N. Sakane, "The relationship between beta 3 -adrenoceptor and regulation of body fat mass, and food intake," Nippon Rinsho, 59, No. 3, 437-442 (2001).

17. A. Baghbanzadeh, M. R. Hajinezhad, B. Shohreh, and R. Maleklou, "Intralateral hypothalamic area injection of isoproterenol and propranolol affects food and water intake in broilers," J. Comp. Physiol. Ser. A. Neuroethol., Sens., Neural Behav. Physiol., 196, No. 3, 221-226 (2010).

18. A. Baghbanzadeh, M. Modirsaneie, G. Emam, and M. Hajinezhad, "Microhandling of vesicular glutamate uptake modulates feeding in broilers," J. Anim. Physiol. Anim. Nutr., 94, No. 1, 74-77 (2010).

19. W. J. Kuenzel and M. Masson, A Stereotaxic Atlas of the Brain of the Chick (Gallus domesticus), Johns Hopkins Univ. Press, Baltimore (1988).

20. M. J. Fregly, N. E. Rowland, C. Sumners, and D. B. Gordon, "Reduced dipsogenic responsiveness to intracerebroventricularly administered angiotensin II in estrogen-treated rats," Brain Res., 338, No. 1, 115-121 (1985).

21. F. S. Tepperman, M. Hirst, and C. W. Gowdey, "A probable role for norepinephrine in feeding after hypothalamic injection of morphine," Pharmacol. Biochem. Behav., 15, No. 4, 555-558 (1981).

22. P. J. Wellman, B. T. Davies, A. Morien, and L. McMahon, "Modulation of feeding by hypothalamic paraventricular nucleus $\alpha 1$ - and $\alpha 2$-adrenergic receptors," Life Sci., 53, No. 9, 669-679 (1993).

23. C. A. Baile, L. F. Krabill, and C. W. Simpson, "Feeding elicited by $\alpha$ and $\beta$ adrenoceptor agonists in sheep and 
cattle," Pharmacol. Biochem. Behav., 1, No. 5, 531-538 (1973).

24. S. Stujii and G. A. Bray, "Food intake of lean and obese Zucker rats following ventricular infusions of adrenergic agonists," Brain Res., 587, No. 2, 226-232 (1992).

25. R. F. Kirby, C. M. Novak, R. L. Thurnhorst, and A. K. Johnson, "The role of beta 1 and beta 2 adrenoceptors in isoproterenolinduced drinking," Brain Res., 656, No. 1, 79-84 (1994).

26. S. Tsujii and G. A. Bray, "A $\beta-3$ adrenergic agonist (BRL37,344) decreases food intake," Physiol. Behav., 63, No. 4, 723-728 (1998).

27. T. Naka, S. Ide, T. Nakako, et al., "Activation of $\beta$-adrenoceptors in the bed nucleus of the stria terminalis induces food intake reduction and anxiety-like behaviors,"
Neuropharmacology, 67, 326-330 (2013).

28. R. Racotta and L. M. Soto-Mora, "Specificity of alpha- and beta-adrenergic inhibition of water and food intake," Physiol. Behav., 53, No. 2, 361-365 (1993).

29. S. F. Leibowitz, "Ingestion in the satiated rat: role of alpha and beta receptors in mediating effects of hypothalamic adrenergic stimulation," Physiol. Behav., 14, No. 6, 743-754 (1975).

30. Y. H. Choi, M. Furuse, J. I. Okumura, and D. M. Denbow, "The interaction of clonidine and nitric oxide on feeding behavior in the chicken," Brain Res., 699, No. 1, 161-164 (1995).

31. H. R. Adams, "Drugs acting on autonomic and somatic nervous system," in: Veterinary Pharmacology and Therapeutics, H. R. Adams (ed.), Iowa State Univ. Press (2001), pp. 69-90. 